\title{
AZ AFRIKAI TAMTAM-OK AVAGY RÉSDOBOK TÖRTÉNETE ÉS TÍPUSAI
}

\section{BRAUER-BENKE JÓZSEF}

Füssi-Nagy Gézától a honi afrikanisztika alapítójától és prominens képviselőjétől gyakran hallhattuk egykoron, ha valamely, az afrikanista hallgatókat érintő fontos közleményről volt szó: „Ez ügyben verjük meg a tamtam dobokat”. Ekképpen néhai, nagy tudású mesterem, rá jellemző módon, a tamtam három lehetséges jelentéstartalma közül mindjárt kettőre is utalt: „2. egyes afrikai népek hosszúkás fadobja 3. biz nagy lárma, zaj valami miatt; hírverés" (Bakos 1984: 834). Azonban a tamtam elsődleges jelentése alapján „kelet-ázsiai eredetü, semleges hangú, gongszerü ütőhangszer" (Uo.) A zenetudomány is ebben az értelemben használja és arra is rámutat, hogy az elnevezés a maláj tammittam hangfestő szóból származik, és a tamtam elnevezésủ gong ütőhangszert Gossec használta először 1791-ben a Mirabeau temetésére írott gyászindulójában (BRZL 3.1985: 485). Emellett arra is rámutat a zenei lexikon, hogy az etnográfiai hangszerismereti irodalomban viszont a fadobot nevezik tamtam-nak, illetve a szórakoztató zenében tévesen a tomtom elnevezés helyett terjedt le a tamtam (Uo). Ez utóbbi téves elnevezés valószínűleg a megszólaltatás módja miatti analógia hatására kerülhetett át egy másik hangszertípusra, mert a tom-tom Nyugat-Európában az afrikai és a keleti dobokra alkalmazott terminus, amit ilyen formájában 'egzotikus dob' jelentéstartalommal használtak (NGDMI 3.1984: 605). Az etnográfiai szakirodalomban elterjedt elnevezésre magyarázatul szolgálhat, hogy a résdobra a tamtam elnevezést Kamerunban az eton népcsoport is használta, ami ilyen formán szintén szélesebb körben ismertté válhatott (Quersin 1986: 168). Ezért az adatok áttekintése alapján úgy tünik, hogy két különböző eredetű, de hasonló hangzású elnevezés olvadhatott egybe. Viszont hangfestő, hangutánzó kifejezésként a tamtam összességében jobban visszaadja a fából készített résdobok hangját, mint egy fémből kovácsolt hangszerét, amelyre viszont a gong hosszabban elnyújtott hangzása tủnik találóbbnak.

A különböző funkcióban történő használata miatt, a hangszertípusnak több megnevezése is elterjedt, úm. slit-gong 'rés-gong', slit-drum 'rés-dob', talking-drum 'beszélő dob', signal-drum 'jelző dob', war-drum 'harci dob' (Carrington 1949: 6). Ezen elnevezések nagy részével az a baj, hogy csak adott funkcióra utalnak, holott több funkcióban (üzenetközvetítö, harci és zenei) is használhatták a hangszert. A hangutánzó tamtam elnevezéssel továbbá az a gond, hogy idiofon (a hangszertest a hang forrása) gongot és membranofon (rezgő membrán a hang forrása) dobokat 
egyaránt jelölhet. Mindezek figyelembe vételével a résdob elnevezés, ha nem is tökéletes (mert a dob hangszernév leginkább a membanofon hangszereket jelöli), de a német Schlitztrommel, a francia tambour à fente, és az angol slit-drum megfelelőjeként talán a legjobb választás lehet (De Hen 1960: 46). A résdob tehát olyan fából készített idiofon hangszer, amelyen egy rést alakítanak ki és ütéssel szólaltatják meg (Sachs 1913: 189). E definíció leginkább a kongói résdobokra igaz, ezért az ázsiai és óceániai résdobok figyelembe vételével bronzból és bambuszból készített résdobokkal is kiegészítendő (Steinmann 1938: 240) és (Kunst 1949: 6).

A résdobok valószínűsíthetően már a neolitikum idején kialakulhattak; korai formájukban lábon álló, kiszáradt fákra vágtak egy hosszanti hasítékot vagy több hangkeltő nyílást, mint amilyenek a Maláj-félsziget hegyvidéki területein élő negrito szemang népcsoport résdobjai (Collaer 1965:110). Közép-Amerikában a teponactli résdobok már az olmék (Kr.e. 1500-400) kultúrában ismertek voltak és egy korai kőből készített példány a Kr.e. 800 körüli időszakból maradt fenn, amely formáját tekintve rokonítható a zapoték ábrázolásokon (Kr.e. 3-Kr.u. 7) látható és azték időszakból fennmaradt (1350-1521) diófából készített, antropomorf résdobokkal (Marti 1967: 114). A hangszer díszítése polinéz karaktereket mutat, ami egyéb kerámia és tánctípusbeli egyezések mellett egy korai óceánia-délkelet-ázsiai és közép-amerikai kapcsolatra utal (Uo). (1. kép)

A szubszaharai Afrika térségében a résdobok leginkább Közép-Afrikában és kisebb mértékben Kelet-és Nyugat-Afrikában elterjedtek, viszont Dél-Afrikából nincsenek adatok a hangszertípus elterjedtségéről, ezért ebben az esetben az Egyenlítői Afrika térség résdobjairól beszélhetünk. Óceánia, Délkelet-Ázsia és Egyenlítöi Afrika területein egyaránt elterjedt animisztikus nézet szerint a résdob teste a női szeméremtestet és a rés, illetve az ütők a férfi nemi szervet szimbolizálják (Sachs

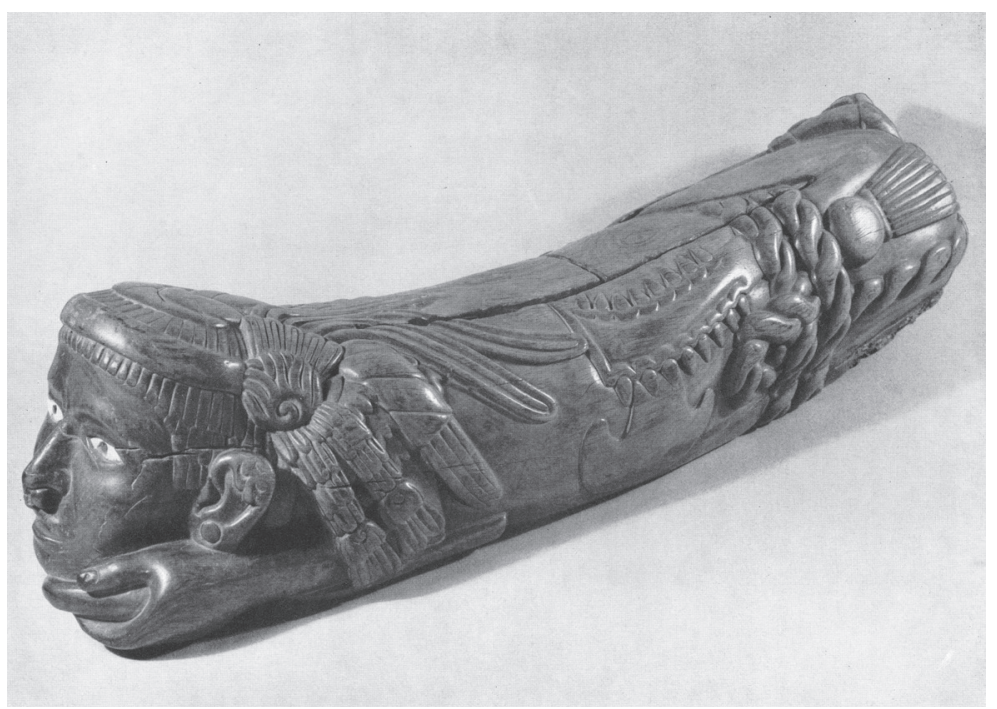

1. kép: Azték teponaczti résdob (Collaer 1967 nyomán) 


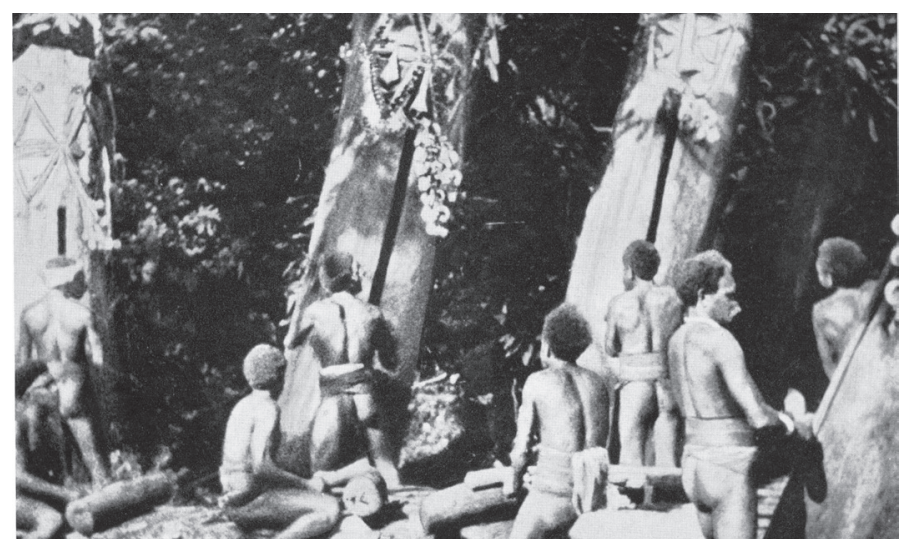

A 2. kép: Melanez antropomorf résdobok (Collaer 1965 nyomán)

1942: 37). (2. kép) Az afrikai résdobok leginkább az Óceánia keleti részén elterjedt pápua résdobokkal mutatnak hasonlóságot, ezért a morfológiai hasonlóság okán felvetődött annak a lehetősége, hogy más hangszerekhez hasonlóan a fából készített résdobok is délkelet-ázsiai közvetítéssel érkeztek az afrikai kontinensre (Frobenius 1981: 331). Ez nem azt jelenti, hogy keletröl nyugatra haladva ugyanazt a hangszertípust adták-vették egymás között a különböző népcsoportok, hanem az ún. stimulus diffúzió jelenségének lényege szerint, nem feltétlenül az új termék, jelen esetben a résdobok átvételéről van szó, csak a hangszertípus ötlete, (úm. egy farönkbe rést vájva hangszertípust lehet létrehozni), adja meg a stimulust a helyi invenció létrejöttéhez (Kroeber 1940: 1). Másrészt a hangszerek konkrét átvételével is lehet számolni, mert a résdobok annak idején, hírközlő funkciójú innovációként vagy újdonságként ható hangszerként egyaránt népszerüek lehettek. Példának okáért a Kongói DK északkeleti részén, az Uele folyó mentén élő mbuti pigmeusok a szomszédos lese népcsoporttól nemcsak azok Nílus-szaharai/közép-szudáni nyelvét vették át, hanem a lesék zenei fesztiváljai alkalmával azok zoomorf résdobjain rendszeresen a kiváló zenésznek tartott mbuti muzsikusok játszanak (Arom-Dournon 1986 178). (3. kép)

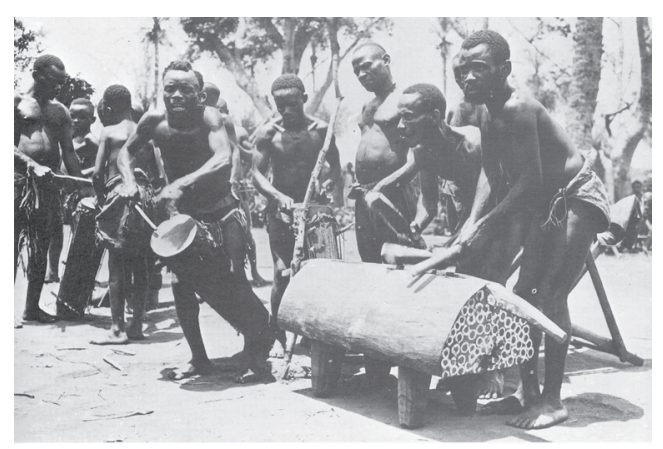

3. kép: Mbuti pigmeus zenészek zoomorf résdobbal (Gansemans-Schmidt-Wrenger 1986 nyomán) 
Mivel a Kongó-medence térségében élö népcsoportok körében a résdobok használatának erős kulturális beágyazottsága figyelhető meg, feltételezhető, hogy a Dél-Afrikában is megtelepedő bantu nyelvủ népcsoportok szintén magukkal vitték volna a résdobjaikat a déli irányú vándorlásaik során. Ebből következik a feltételezés, hogy a résdobok csak a bantu expanzió utolsó 9. századi szakasza után terjedhettek el az Egyenlítői Afrika térségében. A résdobok erős kulturális beágyazottságát jól szemlélteti, hogy a Kongó vidékének hagyományos törzsi társadalmaiban minden fönöknek saját résdobja volt, ami a fönök szakrális és tényleges hatalmát és a falun belüli befolyását reprezentálta, mint például a Kongói DK északkeleti részén élő mayogo népcsoport gugu nevü zoomorf résdobjai (Gansemans 1986: 156). (4. kép) Mivel a törzsfö hatalmának határait a fönöki résdobon közölt üzeneteinek hatóköre szabta meg, igyekeztek minél nagyobb, intenzívebb hangú résdobra szert tenni. A kisebb méltóságok szintén igyekeztek saját résdobot beszerezni, hogy megbecsült tagjai lehessenek a közösségnek. Mivel a résdob egyben a falu erejét is megjelenítette, ezért törzsi háborúk esetén, a győztes fél általában megsemmisítette a legyőzöttek résdobjait, mintegy megfosztva őket a szakrális és a fizikai hatalmuktól. Emiatt az európai gyarmatosítók szintén ezt a módszert követték és a lázadások leverésekor a lázongó falvak résdobját magukkal vitték, hogy lelkileg is megtörjék a legyőzötteket (Laurenty 1968: 209).

A résdobok kulturális beágyazottságának másik jellemző példája, a résdobokkal való üzenetközvetítés. A hangszerekkel való üzenetátadásnak egyik ismert módszere, amikor adott hangszeren egyezményes jeleket játszanak, mint pl. a havasi kürtökkel továbbított kürtjelek, ahol adott zenei frázisnak vagy szignálnak, adott fogalom (pl. farkas vagy rablók járnak a környéken), feleltethető meg. Hasonló módon, a baszkok a txalaparta elnevezésü, fából készített idiofon ütős hangszerüket eredetileg ilyen

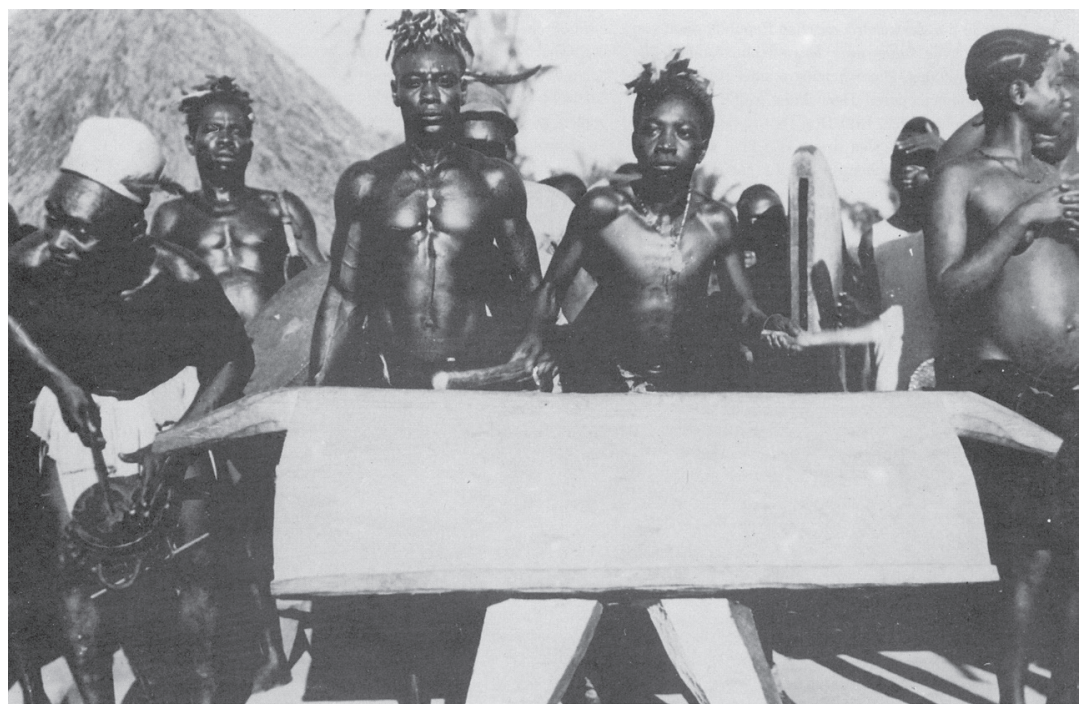

4. kép: Mayogo zenészek gugu zoomorf résdobbal (Gansemans-Schmidt-Wrenger 1986 nyomán) 
fogalom rendszerű (pl. almabor készítés, háború) üzenetátadásra alkalmazták és csak később alakult ki a zenei alkalmazásuk. Az Egyenlítő térségében az amazóniai indiánok, a melanézek és a pápuák, illetve a délkelet-ázsiai szigetvilág népcsoportjai a résdobokat szintén ilyen fogalom rendszerü üzenetközvetítésre használták. Az egyenlítöi Afrika térségében szintén megfigyelhető ez a fogalom rendszerü üzenetközvetítés, mint például Kamerunban, ahol a térség résdobjaitól eltérően a bamiléké résdobok nem ,dobnyelven” közölték a híreket, hanem adott szignál sorozatokkal, amelyek nem képezhetőek le a helyi beszélt nyelvre (Geary 1989, 65). Ezzel szemben Közép-Afrika északi részén, Szudán déli területén, Kamerun és a Kongó-medence nagy részén a résdobokkal való nagy távolságú kommunikációnak kialakult egy sokkal kifinomultabb módja, amivel már nem csak korlátozott számú jellel lehetett üzeneteket közvetíteni, hanem az emberi beszédhez hasonlóan, bővebb információs tartalmakat is meg lehetett jeleníteni (Carrington 1949, 28). Ehhez az is szükséges, hogy a résdobokkal továbbított nyelv tonális jellegü legyen, amelyeknél a szótagok kiejtésénél azok hangmagasságának, illetve annak változásának jelentés megkülönböztető szerepe van. Mivel a szubszaharai Afrika nagy részén elterjedt Niger-kongói nyelvek tonális jellegủek, a legalább két jól elkülöníthető hangmagassággal rendelkező résdobok segítségével a beszélt nyelv dallamát (a magas és mély tónusú szótagok egymásutánját) nagyobb távolságról is jól hallhatóan el tudták dobolni. Mint például a Közép-afrikai Köztársaságban élő banda népcsoport nyelvének hangmagasságára három különböző hang a jellemző és bizonyos szótagok hangmagasságával változhat a jelentésük, ezért két különböző méretű résdobbal leképezhető a nyelv (Arom 1986, 154). Az első dobbal a mély és a közepes hangokat, és a második dobbal a magas hangokat ütik ki és gyakran kiegészítő szereppel egy harmadik dobot is alkalmaztak. (5. kép) Maga a dobnyelv a kódok értéséből áll,

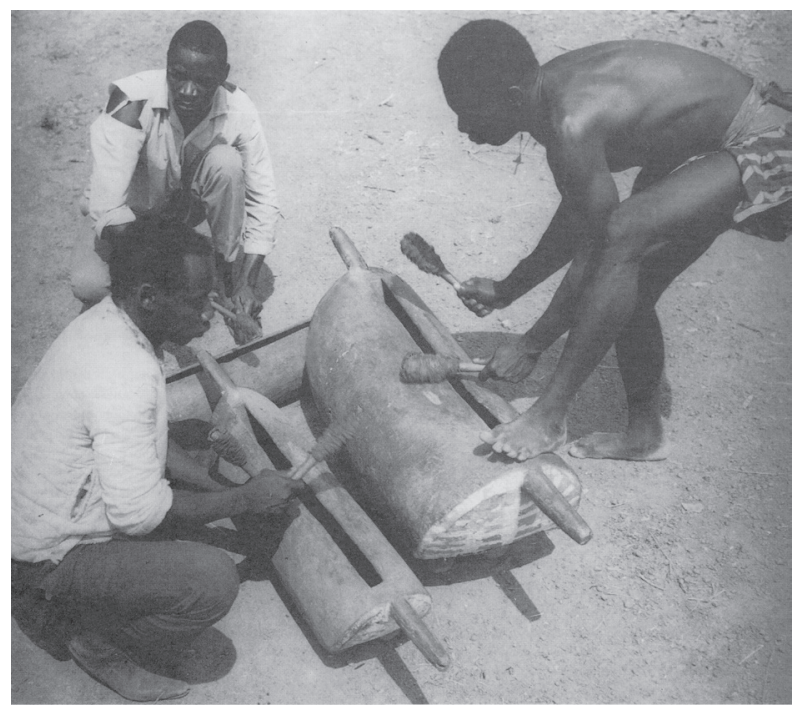

5. kép: Banda üzenetközvetitö résdobok (Gansemans-Schmidt-Wrenger 1986 nyomán) 
amely az adott nyelvre leképezhető, ezért a különböző népcsoportok, különböző ritmusformulákat használtak. A kódolt üzenet egy nyitó hangsorral kezdődött, amit a címzett népcsoport kódja és az üzenet követett, majd egy záró képlettel fejeződött be. Mivel a beszélt nyelv dobbal való megjelenítése információveszteséggel járhat, mert több szó is hasonló tonálitású, ezért a közép-afrikai résdobokon nem adott szavakat, hanem sztereotip frázisok tonális-ritmikai mintázatát dobolták el, ami egyértelművé tette a hírközlést. Ezek a sztereotip frázisok sokszor az üzenetet küldő népcsoport nyelvén megfogalmazott, a szóbeli hagyományban közhelyszerünek számító, mindenki által ismert mondatok, kifejezések voltak (Carrington 1949: 43).

A komparatív hangszerkutatások kimutatták, hogy a résdobok szélesebb körben az Egyenlítő térségében élő népcsoportoknál terjedtek el (Hornbostel 1936: 133). Ehhez kapcsolódóan Dél-Amerikából az Amazonas-medence északnyugati térségéből, (Rivet 1908: 78) Óceánia térségéből pl. Vanuaturól (Speiser 1923: 420) a Salamon-szigetekről (Fox 1924: 25) és Pápua Új-Guineából a Gazella-félszigetről (Eberlein 1910: 24) Délkelet-Ázsiából pedig az Indonéz szigetvilágból főleg Szumátra és Borneó szigetekről (Rutter 1929: 82; és Loeb 1936: 56;) adatolhatóak az üzenetközvetítésre alkalmazott résdobok. Habár az afrikai xilofon hangszertípus és a különböző hangrendszerek (pentaton, heptaton) elterjedésének vizsgálata alapján feltételezik, hogy Kelet, Közép-és Nyugat-Afrika bizonyos területein már az időszámításunk első századaiban megjelenhetett egy indonéz eredetủ népesség (Jones 1964: 126). A későbbi időszakokban, pl. az 5-7. században szintén érkeztek telepesek Kelet-Afrika szabaki nyelvü vidékére úm. ilwana, szuahéli, komorói, rokomó és midzsikenda (Blench 2010, 239). Illetve Madagaszkár szigetén a malgasok ősei, a Borneó déli részéről származó barito nyelvủ maláj telepesek, akik a nyelvészeti kutatások és a régészeti leletek alapján legalább két nagyobb hullámban, valamikor a 8. és a 14. század között érkezhettek a mai lakhelyükre (Dewar-Wright 1993: 318). Az Egyenlítői Afrika térségének legkorábbi résdob ábrázolása a benini királyság 15-16. század közötti időszakából származó réz plakettekről ismert, amely alapján a hangszertípus ábrázolása a kulturális kapcsolatok általi átvételt bizonyítja, mert a yoruba népcsoportnál a hangszertípus nem volt elterjedt. (6. kép) Ezek alapján valószínüsíthető, hogy a közép-afrikai eredetủ hangszertípus a Nigéria keleti részén élő igbo népcsoport által jelenhetett meg a térségben. (Kubik 1989: 102). Ami összességében arra enged következtetni, hogy valamikor a 6-10. század közötti idöszakban jelenhettek meg Egyenlítői Afrikában a résdobok, majd terjedhetett el a használatuk keletről nyugati irányba és alakulhattak ki a formailag és funkcionálisan is eltérő helyi változatai.

Az Egyenlítői Afrika térségében készített résdobok méretükben, formájukban, és felépítésükben is nagyon eltérőek, azonban mindig fából készülnek, amit egy darabban, sokféle külső formára faragnak ki. Közös jellemzőjük, a belsejükben kialakított, a hangszertest formájához alkalmazkodó üreg, amit a résen benyúlva, hosszú nyelü forgácsoló szerszámokkal alakítottak ki. Más hangszertípusokhoz hasonlóan, a kontinens etnikai-nyelvi sokfélesége miatt, a résdobok típusait sem az eredeti elnevezésük tükörfordítás alapján, hanem morfológiai szempontok szerint 


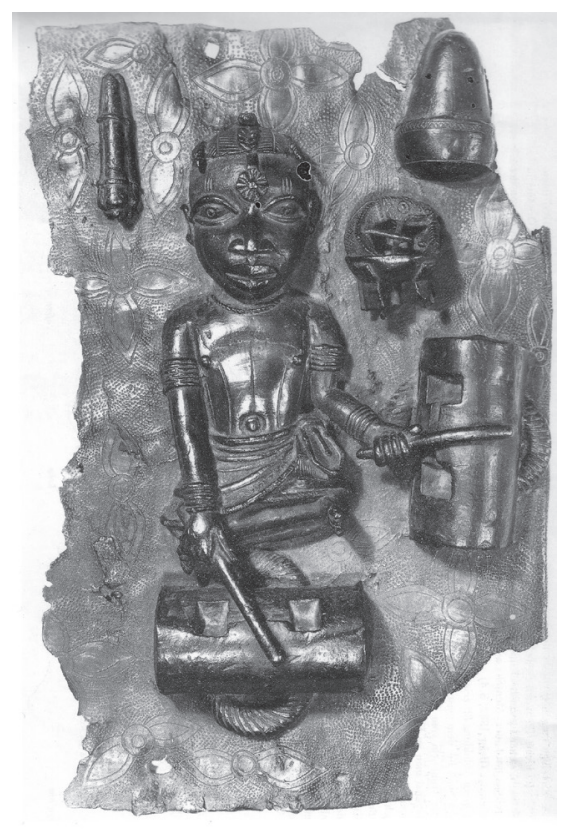

\section{6. kép: Résdob ábrázolás egy benini bronzplaketten (Kubik 1989 nyomán)}

érdemes típusokba sorolni. Ezek alapján megkülönböztethetünk 1. fejsze (trapéz), 2. Proa (több törzsủ vitorlás hajó), 3. tulipán vagy harang 4. konvex (domború) trapéz 5. lapos négyszögletes, 6. lábakkal ellátott hengeres, 7. zoomorf (állat alakú), 8. antropomorf (ember alakú) típusokat (De Hen 1961: 47). Más megközelítésben a hangszertest külső formája, a rés formája, illetve a belső üreg sajátosságai alapján Jean-Sébastien Laurenty, a Tervureni Musée Royal de l'Afrique Centrale organológusa az Egyenlítői Afrika területén elterjedt résdobokat már 14 különböző csoportba sorolta (Laurenty 1968: 9-90).

A fejsze vagy trapéz formájú résdobok a Kongó-medence nagy részén előfordultak, és különösen a középső területén voltak elterjedve. Ilyen trapéz formájú típus például a chokwe népcsoport chingufu résdobja, amit az ún. „mahamba” gyógyító szertartások keretében használtak. (Schmidt-Wrenger 1986: 78). A Kongói DK középső területein élő tetela népcsoportnál a kovácsok készítették a lokombe vagy lukombi elnevezésű trapéz formájú résdobokat az (Alstonia congensis) fájából, ami egy kemény, de könnyü trópusi fafajta (Laurenty 1968, 177-78). Egy nagyobb fa törzséből 5-7 résdobot készítettek, úgy hogy kalapáccsal és több különböző hosszúságú vésővel egy hasítékot véstek a fatörzs oldalába. A kivésés után száraz, durva felületü levelekkel a külsejét lepolírozták, majd a rovarok elleni védekezésül növényi oldatokkal átkenik, és a napon kiszárították. A szárítás után egy hajlított vésővel a belsejét kivésve behangolták a résdobot úgy, hogy a két falrészt különböző vastagságúvá alakították és így különböző hangmagasságú oldalakat kaptak. A résdobokat kaucsukborítású ütőkkel szólaltatták meg, és egy kódolt dobnyelvet 
használtak üzenetközvetítésre. A tetela fönököt mindig egy vagy több lukombi résdob kísérte, hogy az érkezését hírül adják és fenntartsák a kapcsolatot a népcsoport tagjaival (Gansemans 1986: 166). (7. kép)

A Kongói DK délnyugati részén a luba népcsoport falun kívüli hírközlésre használta a trapézformájú nkumvi elnevezésủ résdobját, amely a légköri viszonyoktól függően 10-20 km hatótávolságú szignálhangszerként funkcionált (Gansemans 1986: 156). A falun belüli hírközlést viszont aerofon hangszerekkel és ütött harangokkal oldották meg. Mivel a nkumvi résdobokkal a beszélt nyelv dallamát imitálták, ezért a dobosnak ismernie kell az adott nyelvjárás dallamát és ritmusát, és ezt kell átalakítania a dobnyelvre. A nkumvi dobosoknak a sajátjukon kívül 2-3 környékbeli nyelvjárását is ismerniük kellett, ebböl kifolyólag különleges szociális státuszuk volt. A hírközlő dobosok kizárólag férfiak voltak. (8. kép) Falvanként csak egy, esetleg 2-3 dobos élt, akik bár igen fontos személynek minősültek csupán a hírközlési

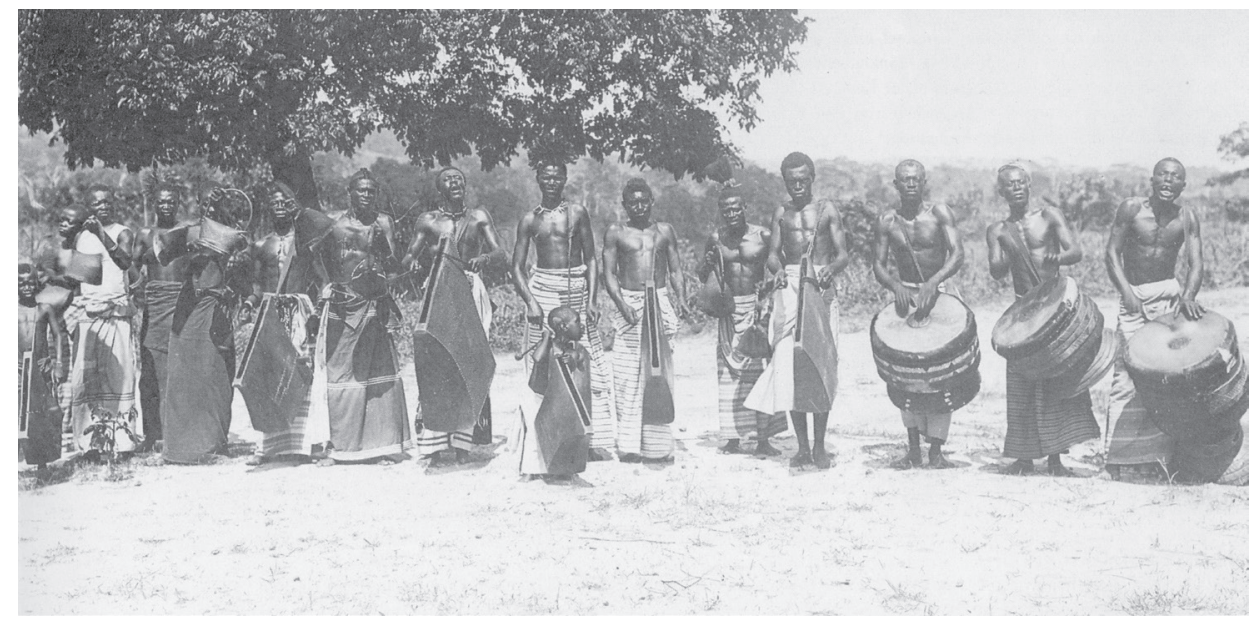

7. kép: Tetela zenekar 1913-ban dobokkal és trapéz formájú résdobokkal (Gansemans-Schmidt-Wrenger 1986 nyomán)

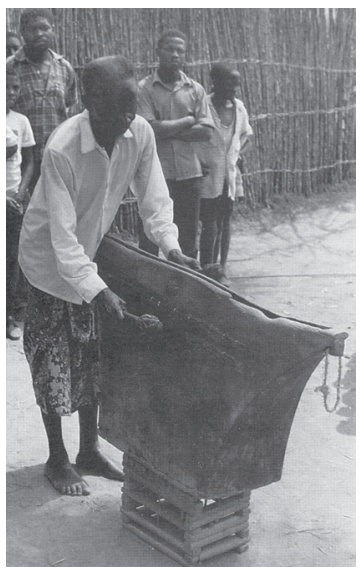

8. kép: Luba dobos, nkumvi trapéz résdobbal (Gansemans-Schmidt-Wrenger 1986 nyomán) 


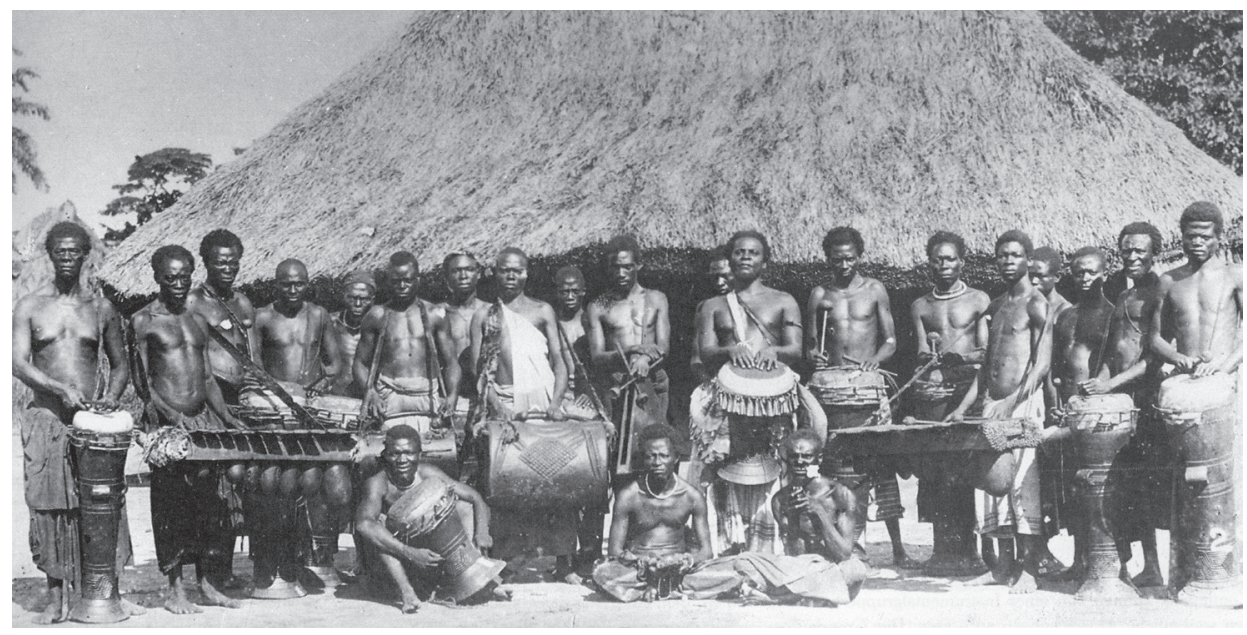

9. kép: Zapozap zenészek 1897-ben dobokkal, xilofonokkal és hengeres résdobokkal (Gansemans-Schmidt-Wrenger 1986 nyomán)

feladatukból nem tudtak megélni. A fönök üzeneteit továbbítva külön jutalomban részesültek. Amennyiben a fönök udvari zenekarában alkalmazták a résdobokat akkor ritmushangszerekként funkcionáltak.

A Kongói DK északi részén élő songye népcsoporthoz tartozó, de attól elszigetelten élö zappo-zap csoport zenéjében igen komoly szerepet játszanak a nyakba akasztható trapéz és henger alakú résdobok. A zappo-zap népcsoport zenei életéről már a 19. század végéről vannak leírások, ezért kimutatható, hogy a 20. században már mind a zenei és táncalkalmak, mind a hangszerek száma erősen csökkenő tendenciát mutatott (Gansemans 1986: 166). (9. kép)

A proa (több törzsü hajó) vagy más megközelítés szerint „en forme de croissant” formájú, kisméretủ résdobok főleg a Kongó alsó folyása mentén voltak elterjedve (Laurenty 1968: 67-75). Ilyen résdob típus Kongói DK délkeleti részén a lemba népcsoport beavatási és gyógyító rítusoknál használt nkonko, amit a helyi varázslók a „ngana lembák” szólaltattak meg (Thompson 1989: 42). A beavatási szertartásoknál a lembák körtáncukkal, amelyben a nap a világot teremtő,ősforrást” jelképezi, megjelenítették a nap járásának körforgását és a négy állomását úm. hajnal/dél/alkony/

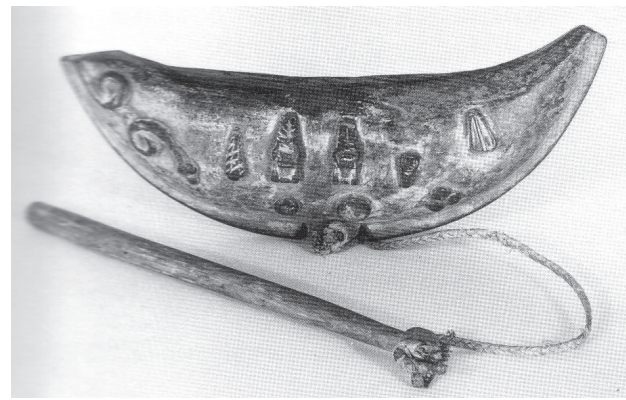

< 10. kép: Lemba kézi résdob bidimba írással (Thompson 1989 nyomán) 
éjfél. A nkonko résdobok egyik oldala a látható, élő világot, a másik oldala pedig a nap körforgását jelképezi, amely a halált is magába foglalja (Thompson 1989: 43). A nkonko résdobok oldalán a lemba ideografikus (fogalmakat jelölö) írással a „bidimba” jeleivel, különböző proverbiumok és mitologikus szimbólumok vannak kivésve. (10. kép) A szimbólumok közül a pálma jelentése az ismert proverbiumra utal, „kiyala-mooko, kufwa ko” vagyis „aki egy pálmát ültet, soha nem fog meghalni", mert a nagylelkủség és az adományozás pozitív sorsot von maga után, ezért a lembáknál az összeadandó párokat pálmafa alá ültették (Uo). A tengeri kagyló a hallhatatlan ösöket és ezáltal az örökéletet jelképezi, míg a spirális forma az ember és a teremtő nap közti kapcsolatra utal, amely a fényével az egész világot beragyogja. A nkonko oldalán jellemző szimbólum a három fözőkő (mazuku matutu), amelyek a legalapvetőbb emberi igények a ház, a ruha és a táplálék jelképei. Illetve elvont, spirituális értelemben a „mindenható teremető" (Nzambi Mpungu), az ősök szellemeit (bakulee) és az életet (bantu) jelképezik. Ezen kívül elterjedt szimbólum a páros madár figurák alkalmazása, amelyek a házasságot jelképezik, illetve a kígyó (nyoka ya zingama) ábrája, amely a nyugati égtáj és a gonosszal való kommunikáció jelképe. A kígyó a lembák hitvilágában az emberek kapcsolatát jelképezi az őserdővel és a vadvilággal. A kígyón kialakított két hurok pedig az élet és a szellemvilág közötti egységet szimbolizálja.

A tulipán alakú és a konvex trapéz formájú résdobok a Kongó-medence északkeleti részén az Uele folyó térségére voltak jellemzőek, mint a bwende lokuka, a gunda toku, a kutu lokome, a mamvu gogo/gokwo/gulu/rigo és az azandé dundu (De Hen 1960: 59). Ezeknél a résdob típusoknál, kisebb-nagyobb fogantyú részt is kialakíthattak, ami a játéktechnikánál kapott szerepet. (11. kép)

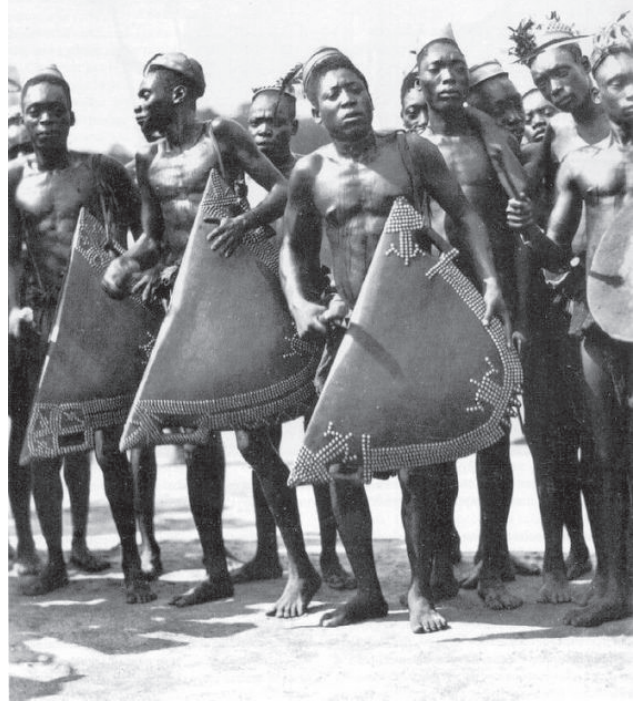

11. kép: Tulipán résdobok (Kongó-videk, 1920-as évek) 
A lábon kiszáradt résdobokhoz hasonlóan a résdobok másik legegyszerübb változata és alaptípusa a hengeres formájú típus, ami egy hosszanti résen keresztül kivájt farönk. Ebből kifolyólag a hengeres típus nemcsak Egyenlítői Afrikában, de a résdobok elterjedési területein mindenhol a legelterjedtebb. Különböző lokális változatai, vízszintesen a földre helyezett, vagy függőlegesen a földbe ásott típusai a dél-amerikai Amazóniában, az óceániai szigetvilágban, Délkelet-Ázsiában és Egyenlítői Afrikában egyaránt megtalálhatóak. Az afrikai hengeres résdobok elnevezéseinek vizsgálata sokszor arról is tanúskodik, hogy a különböző népcsoportok egymástól vehették a hangszertípust. Mint például a Kongói DK keleti részén élő népcsoportok esetében a bangu-bangu tsh(i)ondo, a holoholo kyondo, a kamfwa kyondo, a luba eshiondo vagy kiondo, a mwanza kyondo, a sampwe kiondo és a vira yondo. A hengeres résdobok kisebb és közepes méretủ változatai a Kongó-medence egész területén elterjedtek, mint a lubák hírközlésre használt hengeres résdobja vagy a nkundo népcsoport ingolongolo vagy az ezzel rokonítható impolo népcsoport bonggo résdobja, amiket viszont jellemzően tánckísérethez használnak (Laurenty 1968: 134). (12. kép) Ezzel szemben a nagyobb méretű 2-3 méteres, henger alakú résdobok leginkább a Kongó-medence északi részén fordultak elö, mint pl. a bumba lingele, a mongo lokole, a ngbaka kendungu, és a ngbandi bubu és makilungu (De Hen 1960, 57). Szintén ide sorolható a Közép-Afrikai Köztársaságban a banda népcsoport linga vagy lenga elnevezésű, lábakkal ellátott hengeres résdobja, amelyek különböző nagyságú változatait, adott szertartások keretében faragták ki és ennek során mind a táplálkozásban, mind a szexuális életben megtartóztató magatartást kellett tanúsítaniuk a résdobok elkészítőnek (Arom 1986: 158). Habár a lenga résdobok elsődleges funkciója a hírközlés volt, a bandák tánckísérethez is

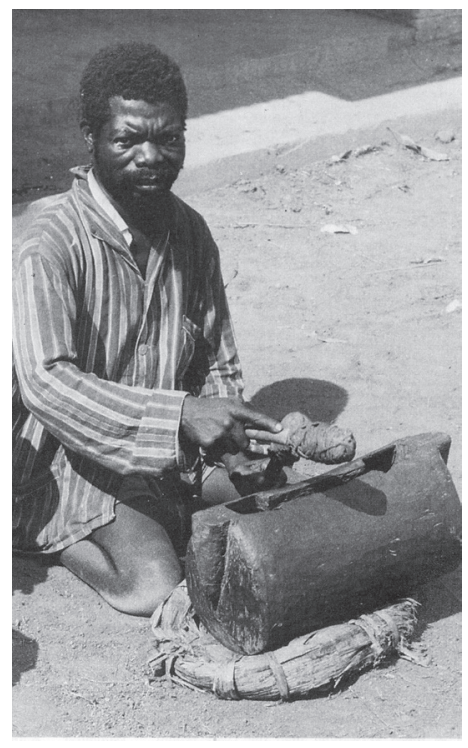

12. kép: Luba henger résdob (Gansemans-Schmidt-Wrenger 1986 nyomán) 


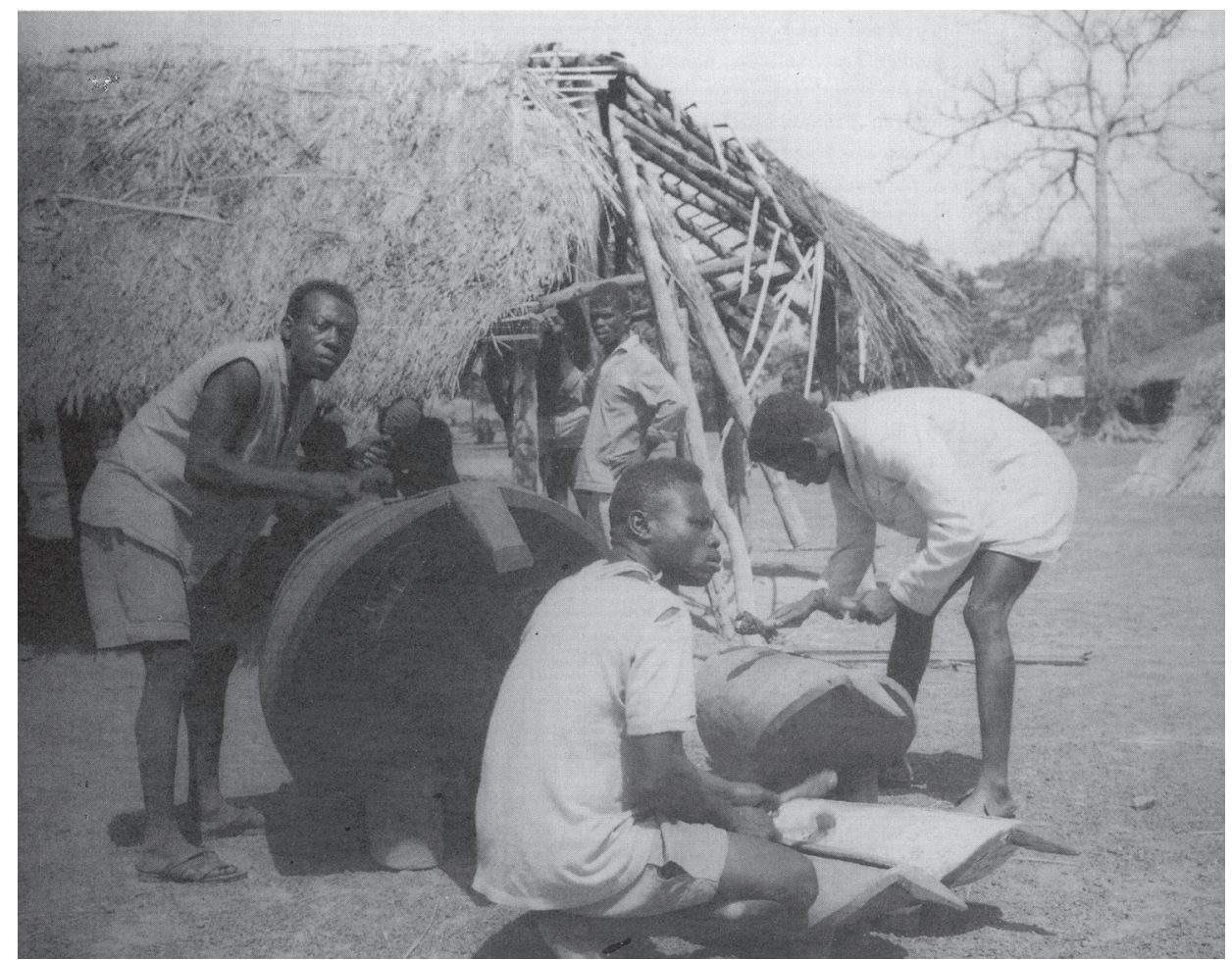

^13. kép: Banda tánckísérö résdobok (Gansemans-Schmidt-Wrenger 1986 nyomán)

használták, amelyek közül a legnagyobb 300 kg-os két méternél hosszabb eyi-lenga vagyis 'anya', illetve a kisebb oko-lenga a 'férj' és legkisebb aya-lenga a 'gyermek'. Ez utóbbiból többet is alkalmazhattak a zenei kíséretnél. (13. kép)

Kamerun nyugati részén a bamiléké titkos férfitársaságok kisebb méretü zoomorf résdobokat használtak, amelyek közül a legelterjedtebb állatalak a bivaly volt, amely az erő és a hatalom jelképe, és amelynek a szarvából készítették az ivótülköket (Geary 1989: 70). A kaméleon és a varangyos béka ábrázolása a résdobok oldalán szintén gyakori volt, mert a kaméleon a betegség, a szerencsétlenség és a halál jelképe, összességében a baljós erők, a boszorkányság szimbóluma. A kaméleon antitézise a varangyos béka, amely a mítoszok szerint szembeszáll a kaméleonnal és a termékenység és a szaporodás szimbóluma. A bamiléké titkos férfitársaságok a zoomorf résdobokat a temetési és a halotti szertartások során használták, ahol a résdob az ősök szellemeinek a hangját szimbolizálta, amely megszólította az uralkodókat és a törvényhozókat. A titkos társaságok tevékenységét a félelem és a titokzatosság aurája lengte körül, amellyel uralmat gyakoroltak a legitim hatalom fölött.

Saját kisméretü zoomorf résdobjai voltak a bamiléké harcos társaságoknak, amelyeknek $n d$ ' $d h i$ vagy $n^{\prime} d u$ volt az elnevezése (Geary 1989: 70). A zoomorf harci résdobok a törzsfő tulajdonában voltak és ezek hangjával hívta csatába a törzsfönök 


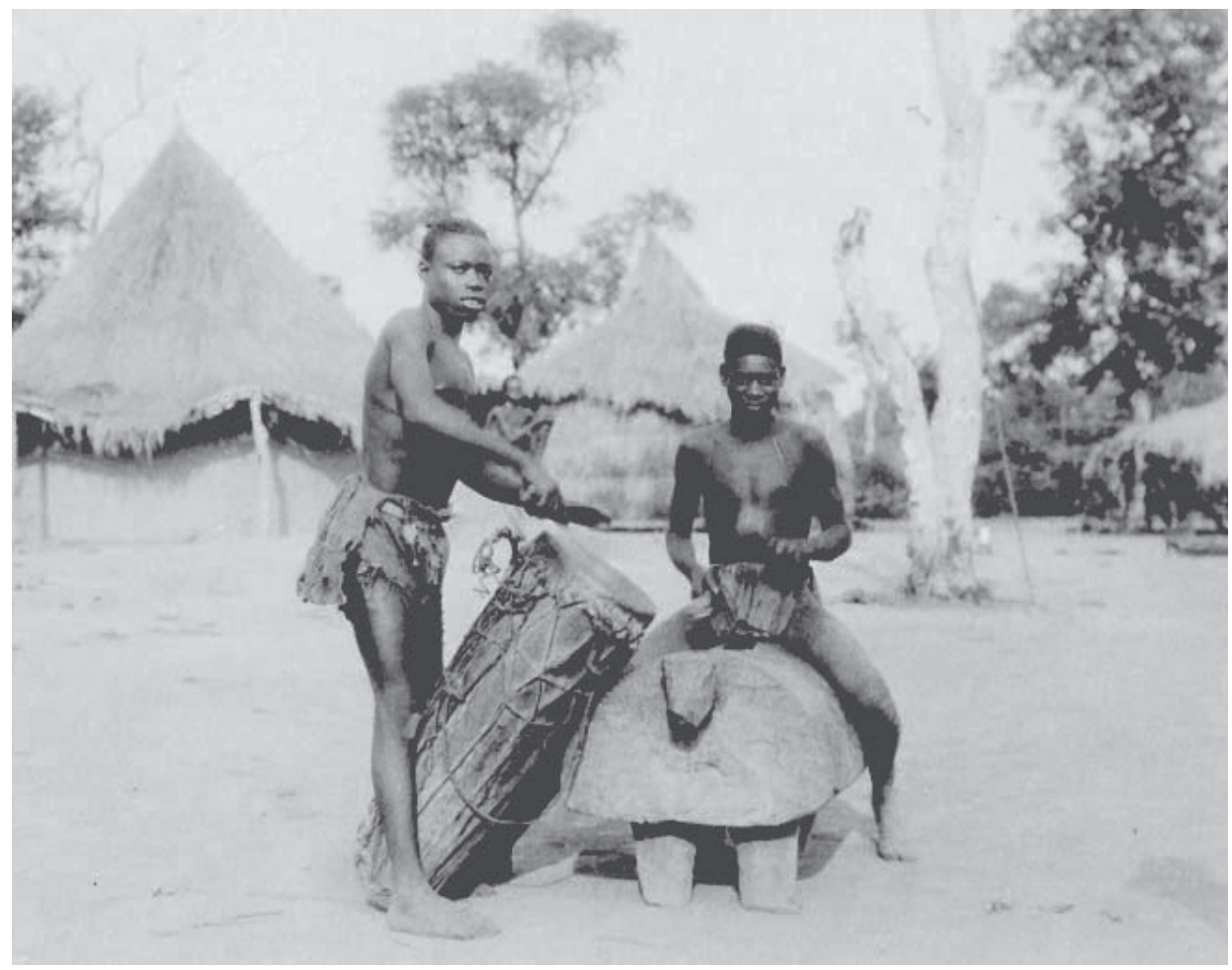

14. kép: Zande zoomorf gugu résdob és kúpdob (1927-30)

az embereit. Ezek a harci résdobok a későbbiekben eredeti funkciójukat elvesztve a kiöregedett harcosok táncának a kísérő hangszereivé váltak. Napjainkban a kameruni résdobok a „ndanji tánc” a királynék táncának a kísérő hangszerei. A résdobok relief díszítésénél az iszlám hatását tükröző hold és csillag formájú díszítések mellett fennmaradtak a bamum motívumok is, mint a csirkebél ábrázolás, amely a jövendömondásnál kapott kiemelt szerepet.

A Kongói DK északi részén élö azandé népcsoport gugu nevü zoomorf résdobjai a főnök hatalmát szimbolizálták. (14. kép) A törzsfö saját gugu dobja volt a legnagyobb, és a hierarchiában utána következő vezetők saját, kisebb gugu dobokkal rendelkeztek. Háború esetén a legyőzött főnök gugu dobját megsemmisítették, megfosztva a fönököt a szakrális hatalmától is. A törzsfö gugu dobját egy külön építményben a résdobok házában tartották, itt volt a férfiak gyülekező helye, itt tartották a tárgyalásokat és itt hirdették ki parancsokat (Gansemans 1986: 156). A résdobokat lehetőleg a folyóhoz közel helyezték el, úgy hogy a mélyebb hangot adó oldaluk a folyó felé nézzen és ily módon akár $10 \mathrm{~km}$-es távolságra is hallhatóak voltak.

Kamerun délkeleti részén a bamum és a bamiléké, illetve északon a tikar királyságokban az antropomorf résdobok különleges fontossággal bírtak. A kindi elnevezésű nagyméretű résdobokat a bamum királyságban a királyi palotában tárol- 


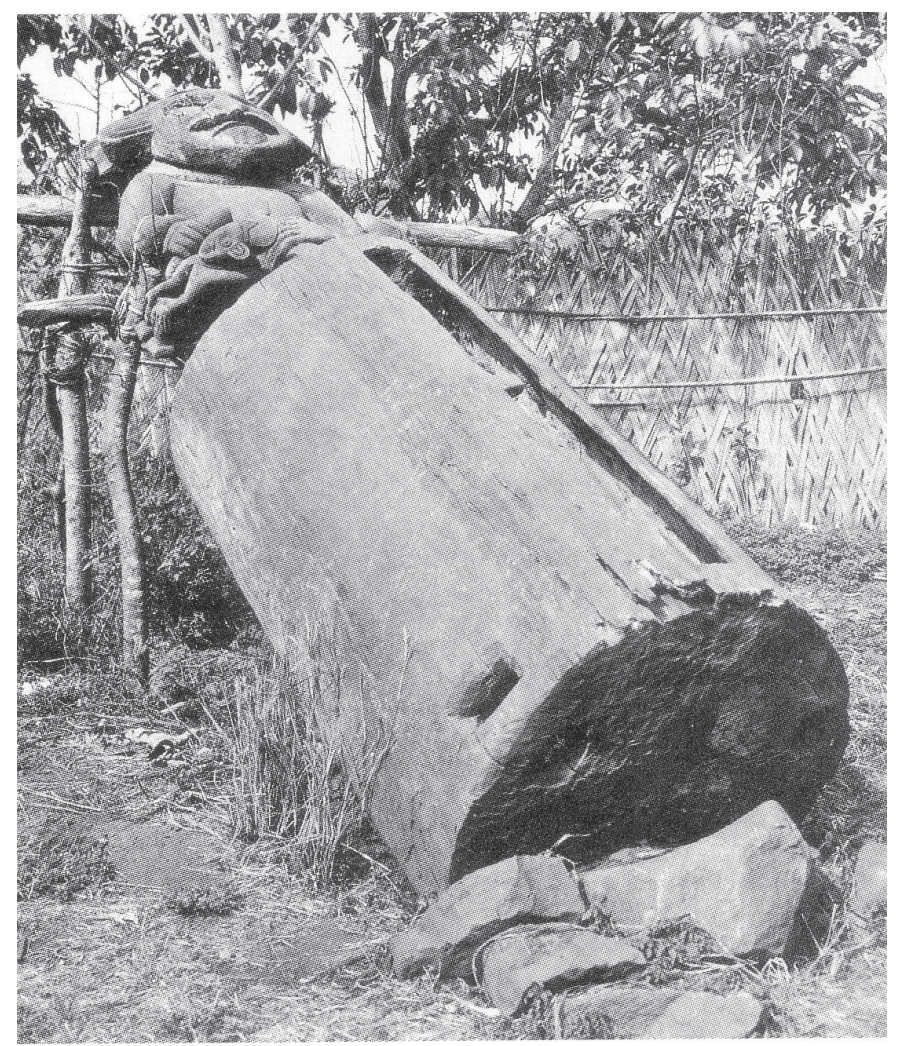

\section{\15. kép: Bamum királyi antropomorf résdob (Geary 1989 nyomán)}

ták (Geary 1989, 64). A kindi résdob hangja több kilométer messziről hallható volt és ennek a hangjával hívták össze a lakókat, ha háború vagy vadállatok támadása fenyegette a királyságot. (15. kép) A bamum népcsoport résdobjainak felső részén jellemző az antropomorf figurák kialakítása. A jobb kezében ivótülköt tartó férfi figura, a nemességet szimbolizálja, akik az ábrázolt ivótülökből itták a pálmabort, kínálták a vendégeiket, illetve mutattak be italáldozatot az ősök szellemeinek. A férfi figura hajfrizurája a muszlim időszak előtti magas társadalmi státuszt jelképezi, míg a balkéz áll támasztása a nyugodtság és a tisztelet szimbóluma (Geary 1989, 67). A bamum népcsoport résdobjain a női figurák az anyakirálynőt jelképezik. A király illetve az anyakirálynő halála esetén a kindi résdobokat kivitték a piactér sarkába és otthagyták őket átadva az enyészetnek, analógiaként a vele spirituális kapcsolatban levő királyi személyiség halálával.

A bamiléké törzsfönökségekben a törzsfő volt a legjobb harcos és a legjobb gyilkos, aki szenvedés okozása nélkül tudott ölni. Ezt a harcos-gyilkos képességet ábrázolták a nke deng résdobok antropomorf figurái, akik a jobb kezükben kardot és a balkezükben az ellenségük levágott fejét tartották. (16. kép) A nke deng résdobokon feltünő állatábrázolások az adott állatra jellemző pozitív tulajdonságokat szimbolizálják. 


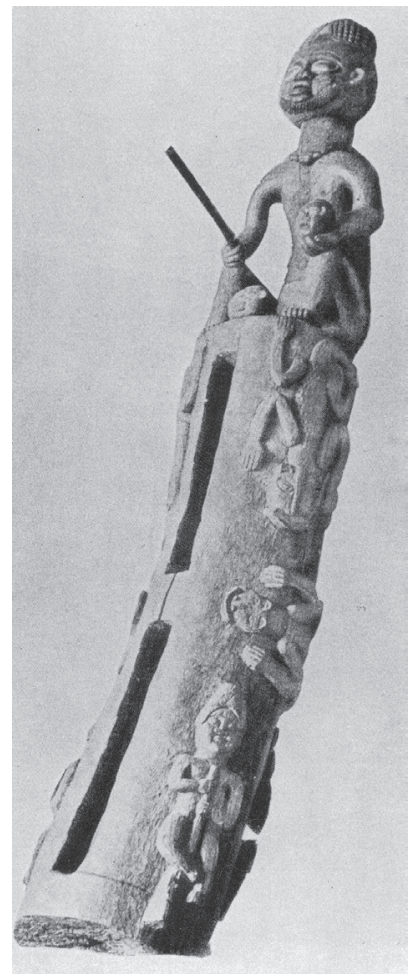

< 16. kép: Bamum törzsfönöki antropomorf résdob (Geary 1989 nyomán)

A lepoárd a ravaszságot és az erőt, míg a pávián a halál utáni átváltozást szimbolizálják és ebből kifolyólag a törzsfök totemisztikus jelképei (Geary 1989, 68).

$\mathrm{Az}$ eredetmítosz szerint Kamerunban az első résdobokat az északi területeken a wen törzsfönökségnél alkalmazták (Geary 1989, 70). A wen törzsfönökségben a hatalom férfiágon öröklődött. Egy alkalommal, bár már volt egy újonnan választott törzsfőnökük, akivel mindenki elégedett volt, de az előző törzsfő fia a leszármazás jogán követelte a törzsfönöki posztot. Tartva az ösök szellemeinek nemtetszésétől lecserélték a törzsfönököt, akinek viszont be kellett bizonyítania, hogy méltó a tisztségre. Az új törzsfönök megbízta a falubeli férfiakat, hogy vágjanak ki egy nagyméretű fát, amiből majd kifaragják az új törzsfőnöki résdobot. Ám a falubeliek valahányszor kivágtak egy megfelelő méretủ fát, amikor másnap visszamentek nem találták sem a kialakított tisztást, sem a kivágott fát. Ezzel tudatták az ősök szellemei, hogy nem fogadják el az új törzsfönököt, ezért a falusiak újból a régi törzsfönököt emelték vissza a posztjára. A történet tanúsága, hogy a törzsfö személye mitikus kapcsolatban áll a résdobbal, illetve a fönöki hatalom tekintetében születési elöjogoknál nagyobb fontossággal bír a spirituális hatalmak támogatottsága (Geary 1989, 72).

Ugyanez ez a nézet tükröződik a kézi résdobok antropomorf kialakításában, amely összefüggésbe hozható az animisztikus vallások őskultusz gyakorlatával. Ennek lényege szerint az ősök szellemei a látható világgal párhuzamos spirituális világban léteznek tovább, ezért ha a különböző rituálék során sikerül őket kien- 
gesztelni, kedvükre tenni, akkor segítik a leszármazottaik életét. Az emberi élet fordulóinak rituális zenei kíséreténél, mint a születés és a halálozás, szintén kisebb méretü, antropomorf résdobokat használtak. (17. kép) A Kongói DK délnyugati részén, Angola határvidékén élö yaka népcsoportnál a nők körülmetélésekor (csikló kimetszése) a mbaala antropomorf résdobot arra használták, hogy annak hangjával elnyomják a nők jajveszékelését, és egy intenzív, monoton ritmust biztosítva megtörték a körülmetélést elszenvedő akaratát, aki ily módon elkábítva kevésbe érezhette a fájdalmat (van Gool 1953: 863).

Kelet-Afrikában, Maliban és Tanzániában szintén használtak kisebb méretủ antropomorf résdobokat, amelyeket az oldal recéssé tételével kaparós hangszerekként is alkalmaztak. (18. kép) Maliban a bambara népcsoportnál a hét évenként megtartott „Jo” beavatási táncok ritmus kíséretéhez használták a három különböző méretü, antropomorf kézi résdobot, amely közül a többi résdob „anyja” a n'keniamba és a másik két maszkulin jellegü résdob, a legnagyobb méretü tium és a valamivel kisebb tierum (Thompson 1979: 89).

Sajnos miként az a zappo-zap népcsoport estén is megfigyelhetö, akik zenei életéről már a 19. század végéről vannak leírások, ezért már a 20. század második felében kimutatható volt, hogy a zenei és táncalkalmaik, és az általuk használt résdobok száma erösen csökkenő tendenciát mutatott, az afrikai résdobok használata, más hangszerekhez képest erősen visszaszorult. Ez a tendencia a hírközlés modernizációjának, és a társadalmi változásoknak egyaránt köszönhetö, mert a hangszer kommunikációs funkciója és a törzsfönöki rendszerhez kötődő spirituális

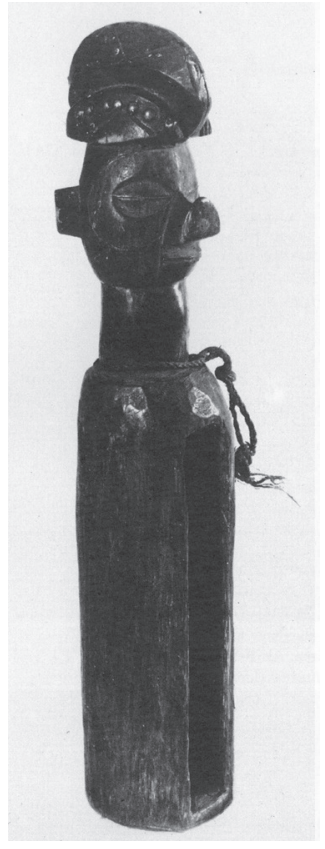

17. kép: Yaka, antropomorf kézi résdob

(Gansemans-Schmidt-Wrenger 1986 nyomán)

18. kép: Bambara antropomorf kézi résdob (Thompson 1979 nyomán)

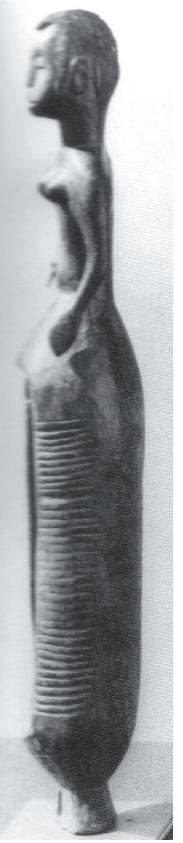


kapcsolata megszünt, és emiatt a résdobok kizárólag hangszerként való alkalmazása erősen korlátozott maradt.

A résdobok adatainak áttekintése alapján összegzésként elmondható, hogy bár egyszerü felépítésénél fogva, ahol fás területek vannak, a résdob típusú hangszerek elvileg mindenhol kialakulhattak volna, de az eddigi adatok tükrében úgy tünik, hogy a hangszertípus vagy annak ötletének átvétele és az Egyenlítö övben való elterjedése az ausztronéz nyelvű csoportok migrációjához köthető. Az átvétel után azonban lokális funkciók és formák alakultak ki. Ennek alapján az Egyenlítői Afrika területén elterjedt résdob típusok keletről-nyugati irányban terjedtek tovább és a hangszertípus dél-afrikai elterjedésének hiánya és az ausztronéz nyelvủ csoportok afrikai megjelenése felveti annak a lehetőségét, hogy a résdobok afrikai megjelenése a 6-10. század közötti időszakra datálható. A hangszertípus kommunikációs funkciója és presztízs jellege miatt, föleg a Kongó-medence népcsoportjai körében terjedt el szélesebb körben. Nyugat-afrikai szélesebb körü elterjedésének viszont akadálya lehetett egyfelől a térségben alkalmazott, hírközlő funkciójában konkurensnek tekinthető membranofon „beszélő” dobtípusok jelenléte, illetve az iszlám 15. századi elterjedésével a hangszertípushoz kötődő animisztikus vallási képzetek átalakulása. Kelet-Afrikában szintén számolni lehet az iszlám 11. századi elterjedésnek köszönhető változásokkal, illetve ezzel összefüggésben a szuahéli nyelv elterjedésével, amely bár bantu nyelv, de nem tonális, ezért összességében a hangszertípus tonális nyelvekkel összefüggő kommunikációs funkciója és törzsfönöki hatalmi jelképként való rituális összefüggésrendszere miatt szorulhatott vissza a résdobok használata a térségben.

\section{Felhasznált irodalom}

- AROM, Simha (1986): Nachrittenübermittlung durch Gruppen von Schlitztrommelspielern bei den Banda. In: Zentral Afrika. Musikgeschichte in Bildern, Bd.1.Lfg.8. Leipzig: Deutcher Verlag für Musik

- AROM, Simha-DOURNON, Geneivéve (1986): Trommelsgruppe der Mbuti während eines festes der Lele. In: Zentral Afrika. Musikgeschichte in Bildern, Bd.1.Lfg.8. Leipzig: Deutcher Verlag für Musik

- BAKOS Ferenc (1984): Idegen szavak és kifejezések szótára. Budapest: Akadémiai Kiadó

- BLENCH, Roger (2010): Evidence for the Austronesian Voyages int he Indian Ocean 239-248. In: The Global origins and development of seafaring. (Eds.) ANDERSON, Atholl-BARRETT, James H-BOYLE, Catherine V Oxford

- BRZL-Brockhaus Riemann Zenei Lexikon 3. (1985): Szerk. DAHLHAUS, CarlEGGEBRECHT Hans Heinrich, Budapest: Zenemükiadó

- CARRINGTON, John F. (1949): A Comparative Study of Some Central African Gonglanguages Brussel:Institut Royal Colonial Belge

- COLLAER, Paul (1965): Ozeanien. Musikgeschichte in Bildern Bd.1. Lfg.1. Leipzig: Deutcher Verlag für Musik

- COLLAER, Paul szerk.(1967): Amerika. Musikgeschichte in Bildern Bd.2. Lfg.7. Leipzig: Deutcher Verlag für Musik

- DE HEN, Ferdinand J. (1960): Beitrag zur Kenntnis der Musikinstrumente aus Belgisch Kongo und Ruanda-Urundi. Inaugural-Dissertation zur Erlangung des Doktorgrades der Philosopischen Fakultät der Universität Köln. 
- DEWAR, Robert E.-WRIGHT, Henry T. (1993): The culture history of Madagascar. In: Journal of World Prehistory. 7.

- EBERLEIN, P. J. (1910): Die Trommelsprache auf der Gazellehalbinsel, Anthropos V. 635642.

- FOX, Charles Elliott (1924): The Threshold of the Pacific, London: Kegan Paul

- FROBENIUS, Leo (1981): Afrikai kultúrák. Válogatott írások. BODROGI Tibor (szerk) Budapest: Gondolat Könyvkiadó

- GANSEMANS, Jos-SCHMIDT-WRENGER, Barbara szerk. (1986): Zentral Afrika. Musikgeschichte in Bildern, Bd.1.Lfg.8. Leipzig: Deutcher Verlag für Musik

- GEARY, M. Christraud (1989): Slit Gongs in the Camerun Grassfields: Sights and Sounds of Beauty and Power. In: Sounding Forms, African Musical Instruments. New York, 63-72.

- JONES, Arthur Morris (1964): Africa and Indonesia. The Evidence of the Xylophone and Other Musical and Cultural Factors. Leiden: Brill

- KROEBER, Alfred Louis (1940): Stimulus Diffusion. Indianapolis, Bobbs-Merill.

- KUBIK, Gerhard szerk. (1989): Westafrika. Musikgeschichte in Bildern, Bd.1.Lfg.11. Leipzig: Deutcher Verlag für Musik

- KUNST, Jaap (1949): The cultural background of indonesian music. Medelingen van de Koinklijke Vereniging Indisch Institut LXXXII. vol. 31. 1-43.

- LAURENTY, Jean-Sébastien (1968): Les tambours á fente de l'Afrique centrale. Tervuren

- LOEB, Edwin Meyer (1935): Sumatra, its history and people. Vienna: erlag des Institutes für Völkerkunde der Universität

- MARTI, Samuel(1967): Teponaztli (Holztrommel) aus Tlaxcala In: Amerika. Musikgeschichte in Bildern Bd.2. Lfg.7. Leipzig: Deutcher Verlag für Musik

- NGDMI-The New Grove Dictionary of Musical Instruments (1981): Szerk. SADIE, Stanley I-III. London: Macmillen Publishers Limited

- QERSIN, Benoit (1986) Ensemblemuzizieren In: Zentral Afrika. Musikgeschichte in Bildern, Deutscher Verlag für Musik.Bd. 1. Lfg.8. Leipzig

- RIVET, Paul (1908): "Les Indiens Jibaros: Etude géographique, historique et ethnographique," L'Anthropologie 19, 69-87, 235-59.

- RUTTER, OWEN (1929): The pagans of North Bornéo, London: Hutchinson \& Co

- SACHS, Curt (1913): Real-Lexikon der Musikinstrumente. Berlin: Verlag Max Hesse

- SACHS, Curt (1942): The History of Musical Instruments. New York-London: J.M. Dent \& Sons

- SPEISER, Felix (1923): Ethnographische Materialien aus dem Neuene Hebriden und den Banks-Inseln, Berlin: C.W. Kreidel

- STEIMANN, Alfred (1938): Über anthropomorphe Schlitztrommeln in Indonesien. Anthropos 33: 240-259.

- THOMPSON, Robert Farris (1979): African art in motion: icon the collection of Katherine Coryton White. Berkeley-Los Angeles

- von HORNBOSTEL, Erich Moritz (1936): Ethnology of African Sound-Instruments. Africa, 129-157, 277-311.

- VAN GOOL, Désiré (1953): Puberteitsriten bij de Bayaka. Anthropos Institut Bd. 48, H. 5./6. 853-888 


\section{English Abstract}

\section{African Tamtams}

A general survey of data leads one to conclude that, even though the slit drum type of instruments, owing to their simple structure, could have developed in any place with abundant tree cover, the available data suggest that the introduction of this instrument type, or the underlying idea, into the equatorial belt can be linked to the migration of speakers of Austronesian languages. After its introduction, however, the instrument type developed in highly localized fnctions and forms. On this basis the widespread slit drum types of Equatorial Africa were passed on in an East-to-West direction; the absence of these instruments in Southern Africa and the date of arrival of Austronesian-speaking groups in Africa suggest the possibility that the appearance of slit drums in Africa can be dated to the period between the 6 th and 10th centuries. The communicative function and prestige value of this instrument type led to its wide adoption among the ethnic groups of the Congo basin in particular. Contrastingly, a major hindrance to its wider distribution over West Africa may have been the presence of a rival candidate for its communicative function (the membranophonic ,talking drums”), as well as changes in the animistic religious concepts linked to this instrument type, a result of widepread conversion to Islam from the 14th century. In Eastern Africa too conversion to Islam from the 11th century and the associated spead of the use of Swahili may have been a significant factor, given the fact that Swahili, while a Bantu language, is not a tone language, and thus the diminished communicative potential of these instruments, dependent on tone, as well as the shrinking ritual aspects of their use as symbols of chiefly authority must have led to the gradual decline of the use of slit drums in this region.
A szerzőrō

PhD, tudományos munkatárs

MTA BTK Zenetudományi

Intézet

About the Author

PhD, Ethno-organologist

Institute for Musicology,

Research Center for the

Humanities, Hungarian

Academy of Sciences

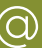

braver-benke.jozsef@btk.mta.hu 

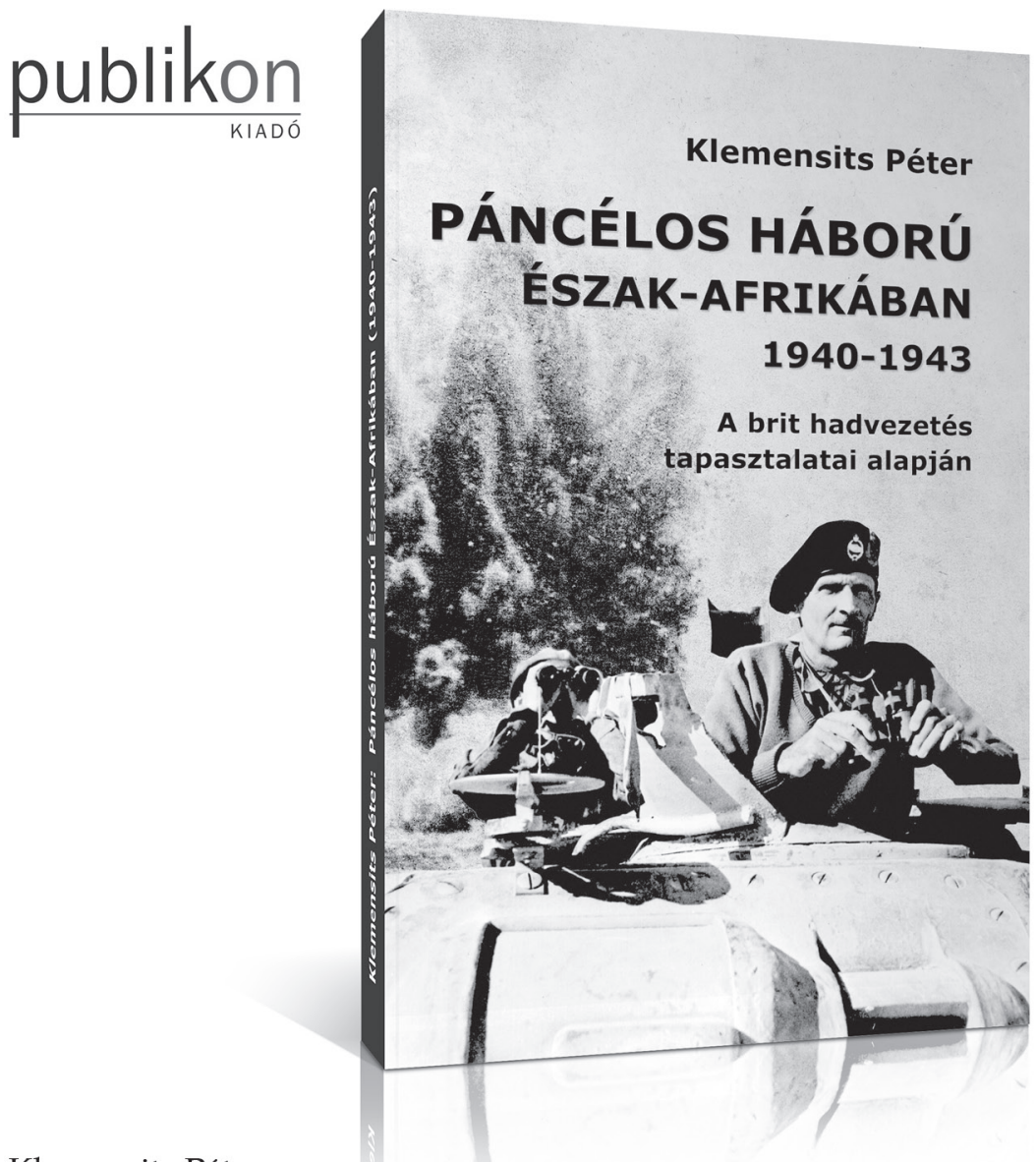

\section{Klemensits Péter}

\section{Páncélos háború Észak-Afrikában (1940-1943)}

A háborús hadszínterek közül mindig is az észak-afrikai volt a legkülönlegesebb, különösen az európaiak számára. Az ókori titkok, a hatalmas ismeretlen, a kietlen sivatagok, a kutatók és a hadtörténet rajongók figyelmét is felkeltették az évek során, korántsem véletlenül. A második világháború során olyan parancsnokok szereztek maguknak hírnevet ezen a hadszíntéren, akiket előtte kevésbé ismert a közvélemény, mint pl. Erwin Rommel vagy Bernard Montgomery. A harckocsi, páncélos pedig nem véletlenül lett az afrikai harcok emblematikus harceszköze.

A kötet tudományos igényességgel foglalja össze mindazon összetevőket, melyek végigkísérték brit páncéloserők alkalmazását Észak-Afrikában 1940-1943 között, különös tekintettel a brit északafrikai hadvezetés hadászati és hadmúveleti tervezésére, a fóbb hadmúveletek bemutatására és a páncéloscsapatok alkalmazásához köthető tanulságok összegzésére. A páncélos fegyvernem alkalmazásán túl viszont az egész észak-afrikai hadszíntér legfontosabb - de kevésbé feldolgozott stratégiai problémái is megjelennek a kötetben, nevezetesen, hogy az olaszok feletti győzelem után miként változott meg a hadászati környezet a britek hátrányára 1941 tavaszán, majd pedig 1942 elején, ez pedig milyen következményekkel járt Észak-Afrikára és a Közel-Keletre nézve, továbbá melyek voltak azok a hadászati döntések, melyek az 1943-as hadmúveletek befejezéséhez vezettek.

Keresse a kötetet a Líra Könyvesboltokban,

a független könyvesboltokban és az internetes portálokon

vagy rendelje meg a Publikon Kiadótól a www.publikon.hu oldalon. 